Article

\title{
Applicability of Membranes in Protective Face Masks and Comparison of Reusable and Disposable Face Masks with Life Cycle Assessment
}

\author{
Huyen Trang Do Thi ${ }^{1}$, Peter Mizsey ${ }^{2}$ and Andras Jozsef Toth ${ }^{1, *(D)}$ \\ 1 Environmental and Process Engineering Research Group, Department of Chemical and Environmental \\ Process Engineering, Budapest University of Technology and Economics, Múegyetem rkp. 3., \\ H-1111 Budapest, Hungary; dothihuyentrang.bme@gmail.com \\ 2 Institute of Chemistry, University of Miskolc, Egyetemváros C/1 108, H-3515 Miskolc, Hungary; \\ kemizsey@uni-miskolc.hu \\ * Correspondence: andrasjozseftoth@edu.bme.hu; Tel.: +36-1-463-1490
}

check for updates

Citation: Do Thi, H.T.; Mizsey, P.; Toth, A.J. Applicability of Membranes in Protective Face Masks and Comparison of Reusable and Disposable Face Masks with Life Cycle Assessment. Sustainability 2021, 13, 12574. https://doi.org/10.3390/ su132212574

Academic Editors: Elena Rada, Marco Ragazzi, Ioannis Katsoyiannis, Elena Magaril, Paolo Viotti, Hussain H. Al-Kayiem, Marco Schiavon, Gabriela Ionescu and Natalia Sliusar

Received: 13 October 2021

Accepted: 9 November 2021

Published: 14 November 2021

Publisher's Note: MDPI stays neutral with regard to jurisdictional claims in published maps and institutional affiliations.

Copyright: (c) 2021 by the authors. Licensee MDPI, Basel, Switzerland. This article is an open access article distributed under the terms and conditions of the Creative Commons Attribution (CC BY) license (https:// creativecommons.org/licenses/by/ $4.0 /)$.

\begin{abstract}
In the COVID-19 pandemic period, the role of face masks is critical as a protective physical barrier to prevent droplets and filtrate exhalations coming from infected subjects or against various environmental threats, including the SARS-Cov-2 virus. However, the plastic and microplastic waste from the used face masks pollute the environment, cause a negative impact on human health and the natural ecosystem, as well as increase landfill and medical waste. The presented paper focuses on providing an overview of the application of membrane technology in face mask products as well as the development of protection mechanisms in the future. The authors performed an environmental analysis of reusable (cloth) masks and disposable masks (surgical masks and filtering facepiece respirators) using the Life Cycle Assessment methodology to assess the impacts on the environment, human health, and ecosystem. IMPACT 2002+ V2.14, ReCiPe 2016 Endpoint (H) V1.02, IPCC 2013 GWP 100a V1.03 methods were applied using specialized software (SimaPro V9.1). The disposable masks consistently provide higher protection, though they also carry several multiple environmental burdens. Conversely, reusable masks improve environmental performance, reduce $85 \%$ of waste, have a 3.39 times lower impact on climate change, and are 3.7 times cheaper than disposable masks.
\end{abstract}

Keywords: face masks; cloth masks; surgical masks; filtering facepiece respirators; Life Cycle Assessment; COVID-19

\section{Introduction}

\subsection{COVID-19 Pandemic in the World}

The COVID-19 pandemic has significant impacts on all areas of life, especially on the health care system. According to the World Health Organization (WHO) study, as of 6:49 p.m. CEST, 8 October 2021, 236,599,025 people have been infected, and 4,831,486 have died during the pandemic so far. The virus has set its mark in all continents: more than 91.0 million people are infected in the Americas, about 71.5 million in Europe, 15.9 million in Eastern Mediterranean, 43.3 million in South-East Asia, 8.8 million in Western Pacific, and 6.1 million in Africa [1]. To slow down the virus's spread, closures and travel restrictions have been set in many places, with devastating economic consequences.

The new SARS-Cov-2 virus, which causes the pandemic, spread widely through the airways. The best non-pharmacological control against respiratory diseases is the widespread social distance, i.e., the reduction of close contact between individuals. Where safe separation is not possible, personal protective equipment is an alternative form of protection. Masks are the most essential pieces of personal protective equipment. They provide a physical barrier to droplets from entering the nose and mouth. Their role is particularly important during COVID-19 when carriers can become infected asymptomati- 
cally [2]. The global face mask market's value during the COVID-19 pandemic from 2019 to 2020 rose from 0.79 to about 166 billion USD [3].

\subsection{Face Mask}

The primary purpose of the mask is a preventive barrier; it provides protection for the respiratory system against various environmental threats such as air droplets, aerosols, and nanoparticles in the air (dust storms, industrial emissions), which can cause various cardiovascular diseases. Consequently, the effectiveness of filtration is paramount, which can vary due to several factors, such as size, shapes, properties, airflow, relative humidity, temperature, or speed of facial movement [4]. In general, the quality of the mask and its filtering ability depend on the mask filter itself and external factors. The specification and design of the mask filter largely depend on the chemical composition, thickness, and sealing density of the constituent materials. Viruses (including SARS-Cov-2 virus) are typically up to about $0.1 \mu \mathrm{m}$ in diameter in size. During the breathing, talking, coughing, and sneezing of an infected person, droplets are released into the air, which can contain a large amount of virus. The large size droplets ( $>5 \mu \mathrm{m}$ in diameter) fall, under gravity, quickly to the ground and are transmitted over short distances. In contrast, the tiny droplets or aerosols $(\leq 5 \mu \mathrm{m}$ in diameter) could remain suspended in the air for a significant period and could be inhaled by a healthy person [5]. This particle size can be stopped with great certainty by high-efficiency particulate arrestance (HEPA) filters and various membranes. For these materials, the efficiency measured on Most Penetrating Particle Size (MPPS) is given as a criterion, i.e., the point where the product has the worst efficiency. They are tested individually for each material, but this value is usually around 0.15 to $0.2 \mu \mathrm{m}$, meaning that the filter stops $0.15 \mu \mathrm{m}$ more easily than $0.2 \mu \mathrm{m}$.

There are five basic mechanisms of the filtration of aerosols: diffusion, gravity sedimentation, interception, inertial impaction, and electrostatic attraction [6,7]. The first four mechanisms are mechanical mechanisms in which their efficiency varies for different particles sizes and flow rates [8]. The aerosols whose size is larger than about $1 \mu \mathrm{m}$ up to $10 \mu \mathrm{m}$, the gravity force is the primary impact on the large-exhaled droplets. In this case, gravity sedimentation and inertial impaction are the dominant filtration mechanisms. The diffusion by Brownian motion of gas molecules and mechanical intervention of particles by the filter fibers is a predominant mechanism with small velocities and smaller aerosols $(0.1 \mu \mathrm{m}$ to $1 \mu \mathrm{m})$ [9]. A small particle flows slowly, allowing it more time to move around and giving it a better chance of colliding and sticking to a filter fiber. Diffusion can be negligible for bigger than $5 \mu \mathrm{m}$ particles. The nanometer-sized particles can easily move between the openings in the filter fibers' network. Lastly, electrostatic attraction is well known as a predomination method for removing aerosols with diameter below $0.1 \mu \mathrm{m}$. An electrostatic deposition is difficult to quantify since it requires knowing the charge on the particles and the fibers. The efficiency of electrostatic filters is high at low velocities like the respiratory velocity through a face mask.

The impact of masks on the environment, ecosystem, and human health relies on their type, and the mask using behaviors (e.g., time of use, type of washing, reusability, etc.). Reusable masks have been proposed as safer and more eco-friendly alternatives than disposable masks [10]. According to the World Health Organization (WHO), about 89 million medical masks are required to respond to the COVID-19 each month. In China, about 116 million face masks were produced daily in February 2020, 12 times higher than usual [11]. More than 600 million face masks in Japan were required per month as of April $2020[12,13]$. The mask global average production required about 10-30 Wh energy, wherein $59 \mathrm{~g} \mathrm{CO}_{2}$ eq greenhouse gas is released per single-use mask, including production, packaging, and transportation phases [14]. However, face masks are made mostly from petroleum-based non-renewable polymer materials such as polypropylene and/or polyethylene, polystyrene, polyurethane, polycarbonate, polyacrylonitrile, polyester, which add plastic or microplastic pollution to the environment, produce negative impact on human and animal health, and increase landfill and medical waste [15]. About $75 \%$ of used 
masks will eventually end up in landfills or bodies of water; in cases where the disposal of these wastes is not correctly managed, there can be risks of secondary transmission from contaminated masks [16]. Landfilling of face masks may generate microplastics presented in leachates and may be released into the surrounding environment, entering the food chain [17]. Microplastics cause a negative impact on ecosystems, i.e., abrasions, ulcers, reproductive failure, oxidative stress originating mortality, reduction in the growth rate and feeding, being vectors to other contaminants, etc. They contaminate fresh water and coastal environments and cause several threats to the aquatic environment. We are also exposed to microplastics via the food chain, which results in severe health problems; the microplastic concentrations in a body may increase through bioaccumulation at various higher trophic levels [18]. Plastic materials require longer a time to decompose, and they will remain in the natural for centuries. Because of their small size, these fragments are not traceable and are extremely difficult to remove from the natural environment, so the most effective mitigation strategies must reduce inputs [19]. Furthermore, the emission of $\mathrm{CO}_{2}$ from the production of face masks will potentially contribute to global warming. The polyetherimide used for the ear loops in single-use face masks contributes significant amount, about $90 \% 119.6 \mathrm{~kg} \mathrm{CO}_{2}$ eq per $\mathrm{kg}$ material, to the global warming potential, [20]. However, if other materials replace the polyetherimide ear loops, e.g., synthetic rubber or polyester elastic straps, the global warming potential for manufacturing face masks would be reduced to $11 \%$ or $12.6 \%$, respectively [21]. Two other essential materials to create disposable masks, Polypropylene and High-Density Polyethylene, also emit relatively large amounts of $\mathrm{CO}_{2}$, respectively, 2.8 and $2.9 \mathrm{~kg} \mathrm{CO}$ eq per $1 \mathrm{~kg}$ of material.

\subsection{Different Types of Masks \\ 1.3.1. Simple Face Mask}

The most superficial face mask is a piece of cloth that completely covers the mouth and nose. Mainly used fabric materials such as scarves, sweatshirts, T-shirts, towels, and cloth masks may provide some protection against nanoparticles that fall into the range of virus-containing particles in exhaled breath [22]. The simple cloth mask combines two fabric layers with stretchable earloops; it can easily be sewn at home [23]. Its filtration efficiency is higher than 50\% (100\% cotton T-shirt, scarf, pillowcase, linen, silk); both the vacuum cleaner bag and tea towel also showed a filtration efficiency higher than $70 \%$ [2]. A specific combination of fabrics, such as cotton-flannel, cotton-chiffon, or cotton-silk, in multilayer masks improves the filtration efficiency; it can be as high as $80 \%$ for particles $<0.3 \mu \mathrm{m}$ and more than $90 \%$ for particles $>0.3 \mu \mathrm{m}$. Cotton can significantly change filtration efficiencies. The cotton hybrid mask combines the effect of mechanical and electrostaticbased filtration, see Figure 1 [9]. The cloth masks are not aimed to protect the wearer from infection but rather protect other people from the wearers' germs. They should be changed frequently and properly washed to prevent viruses from surviving.

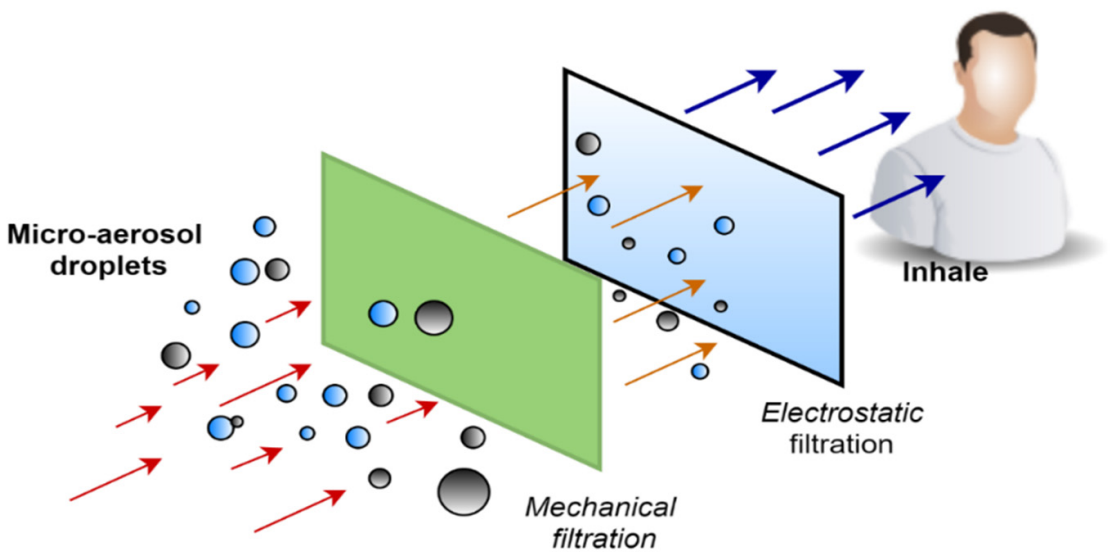

Figure 1. A homemade cloth mask from common fabric materials [9]. 


\subsubsection{Surgical Mask}

Surgical masks are medical devices that comply with an official European Standard (EN 14683) by the Conformité Européene (CE) [24]. According to EU 14683 standard, there are three types of effectiveness: Type 1 (or BFE1), Type 2 (or BFE2) with a bacterial filtration efficiency of over $95 \%$ and $98 \%$, and Type R (IR, IIR), which about resistance to projection, IIR being the most resistant. In the USA, the surgical mask complies with American Society for Testing and Materials standards (ASTM) with three levels of protection: Level 1 for a low risk; Level 2 for a moderate risk; Level 3 for a high risk of exposure the fluids. Doctors and assistants use them to prevent the ability to be infected with germs and pathogens of their patients. This mask has a one-time-use designation, needs to be changed regularly and be disposed of hygienically and safely because most of the droplets from the mouth and throat get stuck in the mask. It is advised to use it for less than $4 \mathrm{~h}$ and replace as soon as it gets wet. Commercially available surgical face masks usually have three layers: the inner layer absorbs moisture, the middle layer is the filter media, and the outer layer repels water, see Figure 2 [25]. The filter prevents particles, aerosols, and pathogens of a specific range from penetrating in either direction. The surgical mask's filtration efficiency is about $90 \%$ [2].

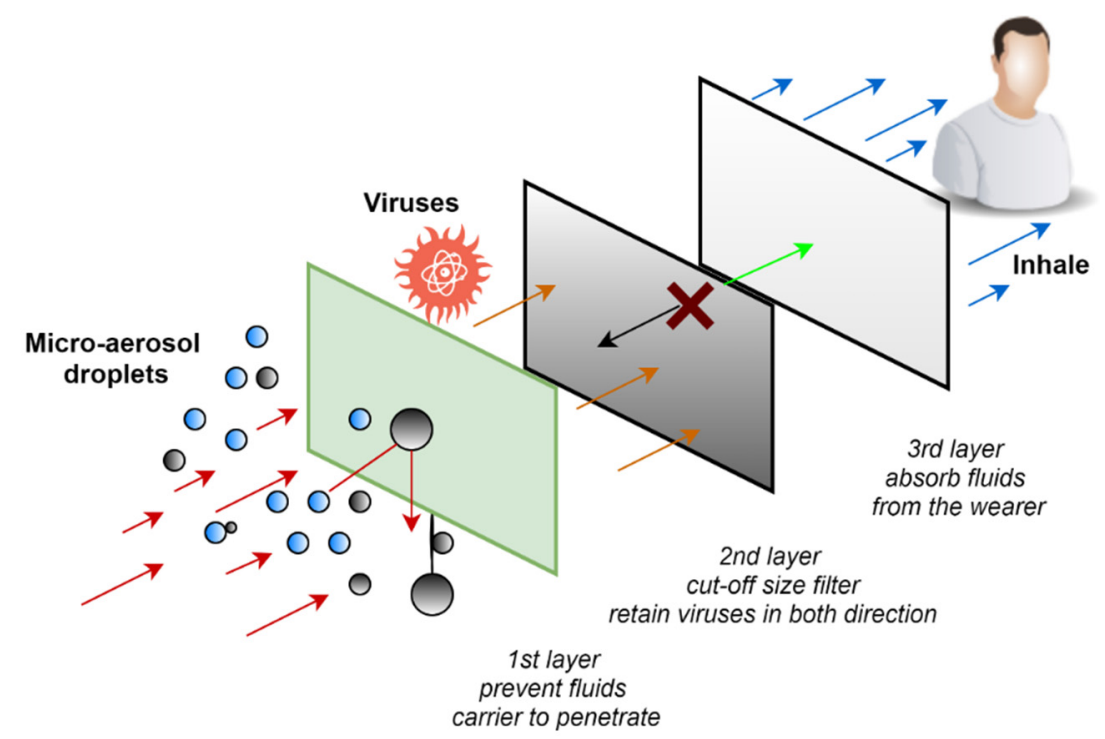

Figure 2. An illustration shows each layer of a surgical mask [2].

\subsubsection{Filtering Facepiece Respirators}

The filtering facepiece (FFP) standards are European Union-certified filter standards for protective masks against dust particles, droplets, and aerosols. The European Standard (EN 149:2001) distinguishes three filter efficiencies referred to as FFP1, FFP2, and FFP3 with corresponding minimum filtration efficiencies of $80 \%, 94 \%$, and $99 \%$ for $0.3 \mu \mathrm{m}$ particles, respectively, as presented in Table 1 [26]. These masks protect the wearer from fine airborne aerosols intended to prevent air impurities from entering the user's respiration, e.g., the FFP1 mask is a specific dust mask used by carpenters, builders, and bricklayers; the FFP1 mask only filters out the biggest particles. Although the protection level of FFP1 masks is better than surgical masks, they do not have the desired protection against viruses. The FFP2 (equivalent to other international standards known as N95 and KN95 mask) provides a broader range of protection for the pharmaceutical industry and protection against the spreading of various respiratory diseases (bird flu, tuberculosis bacteria) [4]. The FFP3 (approximately equivalent to international standards such as N99, EN149) mask protects against even finer particles; although this mask does not provide sufficient protection against gases, it can be said that it includes the protection provided by lower masks. The FFP2 and FFP3 masks are recommended to protect the wearer and those around them 
against the SARS-Cov-2 virus. The FFP mask should not be worn for more than $8 \mathrm{~h}$ in a single day, depending on the conditions of use and the type of respiratory protection device, and the FFP mask should not be reused once removed [27]. The FFP mask's properties are described in Table 1.

Table 1. The FFP mask's properties.

\begin{tabular}{ccc}
\hline Mask Type & Filtration Efficiency for $\mathbf{0 . 3} \boldsymbol{\mu m}$ Particles & Inward Leakage \\
\hline FFP1 & At least $80 \%$ & $<2 \%$ \\
FFP2 & At least $94 \%$ & $<8 \%$ \\
FFP3 & At least $99 \%$ & $<2 \%$ \\
\hline
\end{tabular}

These FFP filters are functionally the same but have different names in other nations [24]. The USA National Institute for Occupational Safety and Health (NIOSH) classifies particulate filtering facepiece respirators (FFRs) into nine categories (N95, N99, N100, P95, P99, P100, R95, R99, and R100): $\mathrm{N}$ is not resistant to oil, not for use in oil droplet environments; $\mathrm{R}$ is slightly resistant to oil and $\mathrm{P}$ is fully resistant to oil, and $\mathrm{R}$ and $\mathrm{P}$ are for use against oily aerosols [26]. Regarding the classification of the mask, the higher the number is, the more protection it can provide and the more functional it can be. The numbers 95,99 , and 100 represent the filter's minimum filtration efficiency for $0.3 \mu \mathrm{m}$ particles, at $95 \%, 99 \%$, and $99.97 \%$, respectively. KN95 mask is closely related to the N95 mask; their differences are negligible, but N95 is the USA standard, while KN95 is the Chinese standard for these close-fitting filtration devices. Both are capable of filtering $95 \%$ of particles of $0.3 \mu \mathrm{m}$ or larger. The efficiency of the N95 and KN95 masks at filtering micro-particles and viruses is the equivalent of FFP2 masks. The Centers for Disease Control and Prevention (CDC) has authorized KN95 masks as a suitable alternative of N95 masks for its response to COVID-19.

Filtration combines a physical barrier of different complex polypropylene microfibers and electrostatic rates [28]. The commercial filtering face mask has four layers: inner, support, filter, and outer layers, see Figure 3. Sometimes, the outer layer has a ventilator fan that permits reinforced breathing, e.g., an N95 mask. The structure and composition of materials in different layers of commercial filtering face masks are shown in Figure 3 and Table 2.

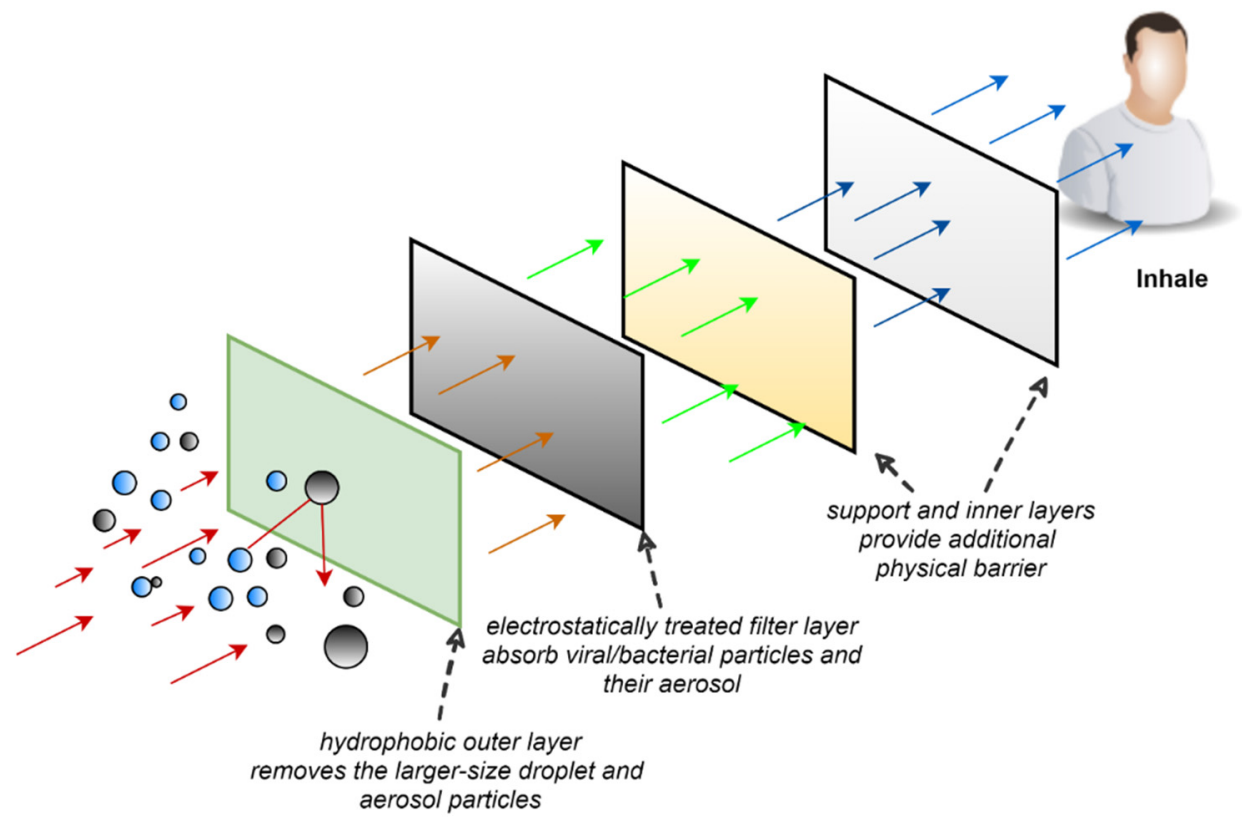

Figure 3. Schematic of each layer of a commercially available filtering face mask [29]. 
Table 2. The functions and materials of each layer in a commercial filtering face mask [29].

\begin{tabular}{|c|c|c|}
\hline Layer of Mask & Function, Assignment & Material \\
\hline Outer layer & $\begin{array}{l}\text { - Hydrophobic, dust-proof } \\
\text { - Physical separation barrier } \\
\text { on bacteria and virus }\end{array}$ & $\begin{array}{c}\text { - Polyester fiber } \\
\text { - Spun-bonded non-woven cloth } \\
\text { - Graphene layer }\end{array}$ \\
\hline Filter & $\begin{array}{l}\text { - For the absorption of } \\
\text { bacteria, viruses, and particles } \\
\text { (PM2.5) } \\
\text { - Electrostatic adsorption, a } \\
\text { physical separation barrier }\end{array}$ & $\begin{array}{c}\text { - Polypropylene-based melt-blown fibric } \\
\text { material } \\
\text { - Nano melt-blown non-woven cloth } \\
\text { - Nano bionic spider web fibric film } \\
\text { - Polyimide (aerogel membrane) } \\
\text { - Teflon } \\
\text { - Inorganic nanoparticles fiber membrane }\end{array}$ \\
\hline Support & Structural support layer & Polyeste fibre net \\
\hline Inner & - Skin-friendly inner layer & $\begin{array}{l}\text { - Cotton-linen } \\
\text { - Modified polypropylene non-woven cloth }\end{array}$ \\
\hline
\end{tabular}

\subsubsection{Comparison of Face Masks}

There are many criteria to compare which masks are suitable for use, such as purpose, effectiveness, cost, comfort, impact on the environment, human health, etc. In this section, the efficiency and filter performance, as well as cost of the mask are focused on for review. Generally, reusable/washable (cloth) masks and disposable masks (surgical masks and respirators) are, indeed, contributing to the reduction of COVID-19 transmission. However, respirators are the highest protection, followed by surgical masks, and finally cloth masks. Additionally, washable masks can be 3.7 times lower in cost than disposable masks [10]. The differences between these masks are summarized in Table 3.

Table 3. Comparison of different types of masks [4,30,31].

\begin{tabular}{|c|c|c|c|}
\hline Types of Masks & Cloth Mask & Surgical Mask & Respirators \\
\hline $\begin{array}{l}\text { Testing and } \\
\text { approval }\end{array}$ & None & $\begin{array}{l}\text { Europe: EN } 14683 \\
\text { China: YY } 0469 \\
\text { USA: ASTM F2100 }\end{array}$ & $\begin{array}{c}\text { Europe: EN 149:2001 } \\
\text { China: GB 2626-2006 } \\
\text { USA: NIOSH (42CFR 84) }\end{array}$ \\
\hline $\begin{array}{l}\text { Intended usage, } \\
\text { purpose }\end{array}$ & $\begin{array}{l}\text { Protect others from the wearer's } \\
\text { respiratory emissions, not fluid }\end{array}$ & $\begin{array}{l}\text { Fluid resistant and protects the } \\
\text { wearer from large droplets }\end{array}$ & $\begin{array}{l}\text { Reduces wearer's exposure to airborne particles } \\
\text { (small particle aerosols and large fluid) }\end{array}$ \\
\hline Breathability & Breathable & Breathable & Difficult \\
\hline Materials & $\begin{array}{l}\text { - Cotton } \\
\text { - Filter paper } \\
\text { - Nylon }\end{array}$ & $\begin{array}{l}\text { - 1st layer: Hydrophobic } \\
\text { Non-Woven } \\
\text { - 2nd layer: Melt blown filter } \\
\text { - 3rd layer: soft absorbent } \\
\text { non-woven }\end{array}$ & $\begin{array}{l}\text { - 1st layer: Polyester fiber, Spun-bonded } \\
\text { non-woven cloth, Graphene } \\
\text { - 2nd layer: Polypropylene-based melt-blown } \\
\text { fibric material, Nano melt-blown non-woven } \\
\text { cloth, Nano bionic spider web fibric film, } \\
\text { Polyimide (aerogel membrane), Teflon, Inorganic } \\
\text { nanoparticles fiber membrane } \\
\text { - 3rd layer: Polyeste fibre net } \\
\text { - 4th layer: Cotton-linen, Modified } \\
\text { polypropylene non-woven cloth }\end{array}$ \\
\hline Leakage & Throughout cloth & Through mask edges & Minimal leakage \\
\hline Face seal fit & Loose-fitting & Loose-fitting & Tight-fitting \\
\hline Filtration & $\begin{array}{l}\text { Low level filtration } \\
\quad(50-90 \%)\end{array}$ & $\begin{array}{l}\text { Moderate level filtration } \\
\quad(\text { About } 90 \%)\end{array}$ & $\begin{array}{c}\text { High/excellent level filtration } \\
(80-99 \% \text {, maybe even } 99.97 \% \text { with N100 for } \\
0.3 \mu \mathrm{m})\end{array}$ \\
\hline Durability & Moderate & Low & High \\
\hline Limitation of usage & $\begin{array}{l}\text { Reusable/ } \\
\text { Washable }\end{array}$ & Disposable & $\begin{array}{l}\text { Discard after each use, but can be used up to } \\
\text { 5-times }\end{array}$ \\
\hline Cost & $\begin{array}{c}\text { Low-cost } \\
(0-0.59 \text { USD/unit })\end{array}$ & $\begin{array}{c}\text { Medium cost } \\
(0.05-0.29 \text { USD/unit })\end{array}$ & High cost (0.18-13 USD/unit) \\
\hline
\end{tabular}




\section{Materials and Methods}

Today, environmental protection is becoming increasingly central to our daily lives. There is a growing need for methods to assess environmental impacts associated with products and to seek to prevent these impacts. The purpose of Life Cycle Assessment (LCA) is to determine the environmental consequences of services, products, or technologies in a specified boundary, e.g., "from cradle-to-grave" [32] that all the phases of a product's life cycle starting the extraction of raw materials through production, distribution, use, possible reuse or recycling, and finally waste treatment. The LCA is comprehensive in terms of the environmental impacts associated with the function. These inputs and outputs are transformed by their impact on the environment. The LCA methodology goes beyond the quantification and evaluation of the environmental performances of the products (goods or services) or processes. It helps decision-makers to choose alternatives. The LCA consists of four phases by ISO 14040-14044 (2006) standards: namely, goal and scope definition, life cycle inventory (LCI), life cycle impact assessment (LCIA), and interpretation [33]. Several impact analysis and evaluation methods have been developed, which strongly affect LCA results, such as CML 2 baseline, Eco-Indicator 99, Eco-Points 97, IMPACT 2002+, $\mathrm{CO}_{2}$ emission, or Carbon Footprints, ReCiPe, Ecoinvent, etc. There are two mainstream ways to obtain characterization factors: midpoint and endpoint level. The midpoint (problemoriented) is only determined by the potential environmental effects and considered to link the cause-effect chain of an impact category [34]. After damage analysis, normalization, and weighting steps, the endpoint has been separated into the damage category and result outcomes for decision-makers [35]. The midpoint indicators are relatively strong scientific robustness, while endpoint indicators are easier to interpret.

The LCA system is often complex with extensive data requirements and a comprehensive chain of processes, which often cannot be fully met in practical applications. Most data are collected on a case-by-case basis about the environmental consequences of technical processes. Software is indispensable for complicated LCA operations. The software database must contain the required data, but in addition, analysis in many cases, such as when specific processes or data need to be modeled, necessitates the construction of a new database. Among the software packages, SimaPro and Gabi are the most popular and valuable tools for LCA assessment. The advantage of SimaPro is a well-known, internationally accepted, validated tool, with simple, flexible, transparent results that are highly interactive, and simple to connect with other tools [36].

\subsection{Goal and Scope}

Life Cycle Assessment (LCA) methodology has been followed to the evaluation of environmental, human health, ecosystem impacts of reusable masks (cloth mask) and disposable masks (surgical mask, FFP2 mask with valve, and FFP2 mask without valve). For the LCA of the face mask, the system boundary includes five phases: mask production from raw materials; packaging and transportation; usage phase; reuse/maintenance phase by disinfection with ethanol or wash; and end of life (disposal). In Figure 4, the system boundary is presented. However, it only considers the manufacturing and reusing (washing) phases, including the necessary energy assumed and materials, which is called "cradle-to-gate" analysis. In this study, the functional unit (FU) is the sum of face masks used in 306 days from March 2020 to December 2020, calculated according to the Italia population. This study gives an overview of the protection efficiency, price, impact on the ecosystem, human health, and environment of the face masks, thus providing a completed sustainability consideration for policy makers for their future contingency plans and motivation for scientists to conduct further research of new environmentally friendly mask materials. 


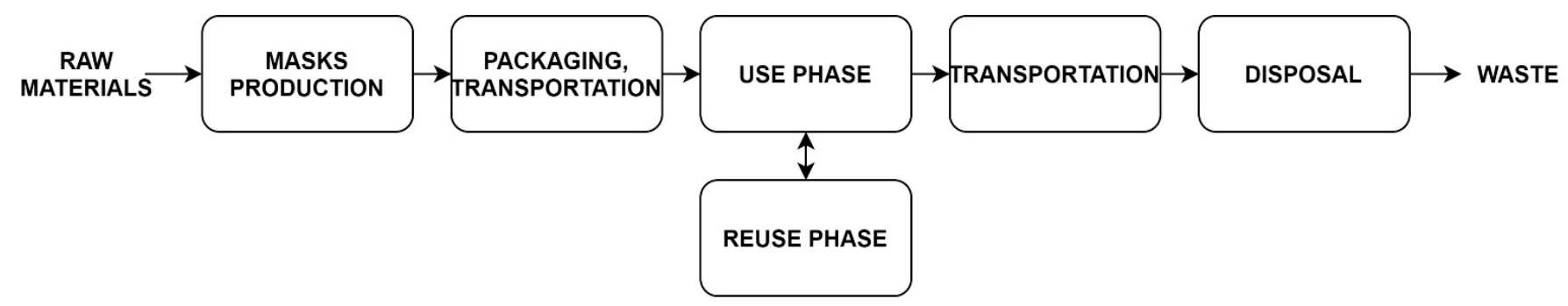

Figure 4. System boundary for LCA of face mask.

\subsection{Inventory Analysis}

This study examined the reusable mask (cloth mask) and disposable masks (surgical mask, FFP2 mask with valve, and FFP2 mask without valve). The data is based on reports/articles by Ayse Lisa Allison et al. in 2020 [20] and Núria Boix Rodríguez et al. in 2021 [37]. As presented Table 4, the study period is 306 days from March 2020 to December 2020 , considering the Italian scenario with about 60 million population and an average of $2.67 \mathrm{~h}$ per day duration that the masks are being worn. Raw materials are imported from China to Italy. Face masks had been produced in Italy, where renewables provided $43 \%$ of Italy's electricity compared to 57\% of fossil fuels (gas, oil, coal) in 2020. The COVID-19 pandemic significantly reduced $6.3 \%$ of Italy's electricity demand and $16 \%$ of electricity net imports in 2020 [38]. This study did not include emissions from material packaging and transport for domestic or export purposes due to data gaps. The electricity consumption is included for cloth mask laying, cutting, sewing, and filter body forming. For manual washing of cloth masks, water is taken from household taps at $20^{\circ} \mathrm{C}$ together with $2.6 \mathrm{~g}$ soap, $2.5 \mathrm{~L}$ water per wash; an average of 2.4 pieces of cloth masks could be washed together; the energy of water is not considered.

Table 4. Raw data for face mask production [20,37].

\begin{tabular}{|c|c|c|c|c|c|}
\hline Mask Type & Material & Value & Unit & Lifespan & $\begin{array}{c}\text { Mask } \\
\text { Required } \\
\text { [Millions] }\end{array}$ \\
\hline \multirow{6}{*}{ Cloth mask } & Polypropylene (filter) & 2.70 & $\mathrm{~g}$ & \multirow{6}{*}{50 washes } & \multirow{6}{*}{280} \\
\hline & Polyester (filter) & 2.70 & $\begin{array}{l}8 \\
\mathrm{~g}\end{array}$ & & \\
\hline & Cotton (bands) & 1.00 & $\mathrm{~g}$ & & \\
\hline & Manual washing & 2.60 & $\mathrm{~g}$ & & \\
\hline & (per wash) water & 2.50 & L & & \\
\hline & Electricity consumption & $3.42 \times 10^{-2}$ & $\mathrm{kWh}$ & & \\
\hline \multirow{5}{*}{ Surgical mask } & Polypropylene (filter) & 1.28 & $\mathrm{~g}$ & \multirow{5}{*}{$4 \mathrm{~h}$} & \multirow{5}{*}{12,240} \\
\hline & Polyester (filter) & 1.28 & $\begin{array}{l}8 \\
g\end{array}$ & & \\
\hline & Aluminium (nose adapter) & 0.44 & $\mathrm{~g}$ & & \\
\hline & Cotton (bands) & 0.02 & $\mathrm{~g}$ & & \\
\hline & Electricity consumption & $7.92 \times 10^{-4}$ & kWh & & \\
\hline \multirow{6}{*}{ FFP2 with valve } & Synthesis rubber (bands) & 3.00 & $\mathrm{~g}$ & \multirow{6}{*}{$8 \mathrm{~h}$} & \multirow{6}{*}{6120} \\
\hline & Polypropylene (filter) & 5.00 & g & & \\
\hline & Aluminium (nose adapter) & 0.95 & $\begin{array}{l}8 \\
g\end{array}$ & & \\
\hline & Polyurethane foam (nose protection) & 0.05 & $\begin{array}{l}5 \\
g\end{array}$ & & \\
\hline & Polypropylene (valve) & 5.00 & $\mathrm{~g}$ & & \\
\hline & Electricity consumption & $5.56 \times 10^{-4}$ & kWh & & \\
\hline \multirow{4}{*}{$\begin{array}{l}\text { FFP2 without } \\
\text { valve }\end{array}$} & Synthesis rubber (bands) & 3.00 & $\mathrm{~g}$ & \multirow{4}{*}{$8 \mathrm{~h}$} & \multirow{4}{*}{6120} \\
\hline & Polypropylene (filter) & 5.00 & $\mathrm{~g}$ & & \\
\hline & Aluminium (nose adapter) & 0.95 & g & & \\
\hline & Electricity consumption & $5.56 \times 10^{-4}$ & kWh & & \\
\hline
\end{tabular}




\subsection{Life Cycle Impact Assessment}

The IPCC 2013 GWP 100a V1.03, ReCiPe 2016 Endpoint (H) V1.02, and IMPACT 2002+ V2.14 are used as methods of impact analysis and evaluation based on the SimaPro Life Cycle Analysis software version 9.1. Pré Sustainability B.V registers the SimaPro software and these methods in the Netherlands. IMPACT 2002+ methodology allocates 14 midpoint categories to 4 damage categories (endpoints) and corresponds to changes in the quality environment [39]. ReCiPe 2016 represents for global scale of the three perspectives (individualist, hierarchist, egalitarian). It harmonizes characterization factors at 18 midpoints and 3 endpoints [40]. The IPCC 2013 GWP 100a method expresses Greenhouse gases (GHGs) emissions in kilograms of $\mathrm{CO}_{2}$ equivalent over 100 years [41].

\section{Results}

LCA results are reported in the following tables (Tables 5-8) for four mask types: cloth mask, surgical mask, FFP2 mask with and without valve based on IPCC 2013, IMPACT 2002+, and ReCiPe 2016 Endpoint methods. Figure 5 visualizes the data from Table 6, which is the result of the LCA assessment with a weighting-single score based on the IMPACT 2002+ method. Normalization facilitates the interpretation of results by comparing each damage type with similar units, allowing the consequences of weighting factors to be estimated and discussed. It can be observed that FFP2 with valve has the highest impact, followed by FFP2 without valve and surgical mask; the lowest is cloth mask with significantly lower results in the climate change, resources, and human health damage categories. The surgical mask has the worst impact on the ecosystem quality, followed by cloth masks, FFP2 with valves, and finally FFP2 without valves. In general terms, the total weighting-single score of cloth masks is 3.55, 2.40, and 1.62 times lower than FFP2 with a valve, FFP2 without a valve, and surgical mask, respectively, which is described in Figure 5.

Table 5. Summary of the results of impact assessment based on the IMPACT 2002+ method.

\begin{tabular}{cccccc}
\hline Damage Category & Unit & FFP2 with Valve & FFP2 without Valve & Surgical Mask & Cloth Mask \\
\hline Human health & DALY & 125 & 85.2 & 65.5 & 68.5 \\
Ecosystem quality & PDF $\times$ m $^{2} \times$ years & $1.28 \times 10^{7}$ & $1.14 \times 10^{7}$ & $3.19 \times 10^{7}$ & $1.45 \times 10^{7}$ \\
Climate change & kg CO 2 eq & $1.75 \times 10^{8}$ & $1.26 \times 10^{8}$ & $8.43 \times 10^{7}$ & $5.36 \times 10^{7}$ \\
Resources & MJ primary & $6.65 \times 10^{9}$ & $4.36 \times 10^{9}$ & $2.51 \times 10^{9}$ & $9.78 \times 10^{8}$ \\
\hline
\end{tabular}

Table 6. Summary of the results of impact assessment with a weighting-single score based on the IMPACT 2002+ method.

\begin{tabular}{cccccc}
\hline Damage Category & Unit & FFP2 with Valve & FFP2 without Valve & Surgical Mask & Cloth Mask \\
\hline Human health & $\mathrm{kPt}$ & 17.7 & 12 & 9.24 & 9.65 \\
Ecosystem quality & $\mathrm{kPt}$ & 0.933 & 0.833 & 2.33 & 1.06 \\
Climate change & $\mathrm{kPt}$ & 17.7 & 12.7 & 8.51 & 5.41 \\
Resources & $\mathrm{kPt}$ & 43.8 & 28.7 & 36.5 & 6.44 \\
Total & $\mathrm{kPt}$ & 80.133 & 54.233 & 36.58 & 22.56 \\
\hline
\end{tabular}

Table 7. Summary of the results of impact assessment based on the IPCC 2013 method.

\begin{tabular}{cccccc}
\hline Damage Category & Unit & FFP2 with Valve & FFP2 without Valve & Surgical Mask & Cloth Mask \\
\hline IPCC GWP 100a & $\mathrm{kg} \mathrm{CO}_{2 \text { eq }}$ & $1.96 \times 10^{8}$ & $1.37 \times 10^{8}$ & $9.20 \times 10^{7}$ & $5.78 \times 10^{7}$ \\
\hline
\end{tabular}


Table 8. Summary of the results of impact assessment based on the ReCiPe 2016 Endpoint method.

\begin{tabular}{cccccc}
\hline Damage Category & Unit & FFP2 with Valve & FFP2 without Valve & Surgical Mask & Cloth Mask \\
\hline Human health & DALY & 377 & 253 & 190 & 169 \\
Ecosystem quality & Species $\times$ years & 0.817 & 0.553 & 0.503 & 0.518 \\
Resources & USD2013 & $4.44 \times 10^{7}$ & $3.44 \times 10^{7}$ & $1.80 \times 10^{7}$ & $4.59 \times 10^{6}$ \\
\hline
\end{tabular}

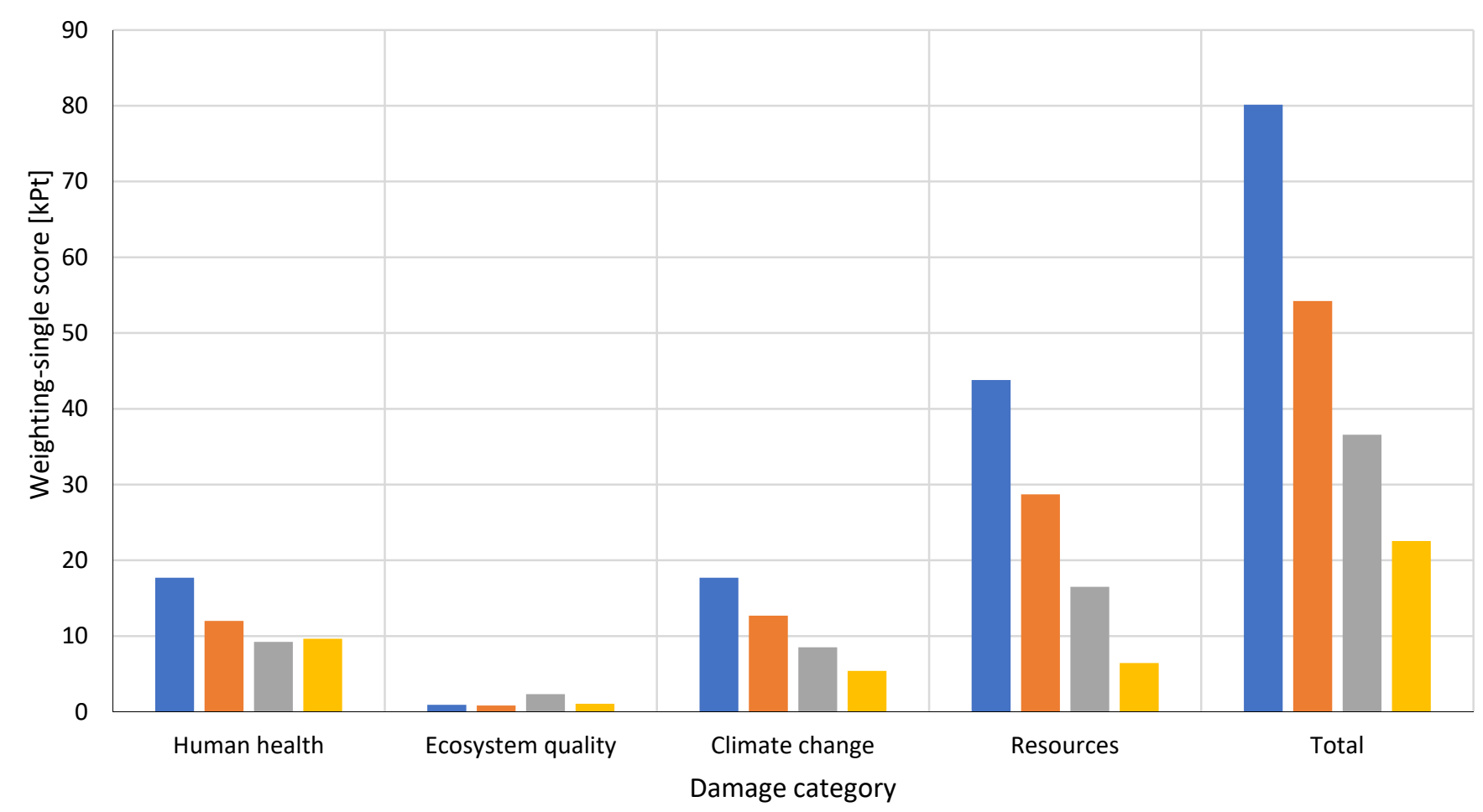

aFP2 with valve $\quad$ FFP2 without valve $\quad$ Surgical mask $\quad$ Cloth mask

Figure 5. Comparison of reusable and disposable masks with weighting-single score based on IMPACT 2002+ method.

The LCA mid-point impact category results based on the IMPACT 2002+ method are reported in Table 9. It can be observed that, regarding the impact categories, FFP2 mask with valve has the biggest impact, followed by FFP2 mask without valve, surgical mask, and cloth mask with significantly lower results. The impact category in which FFP2 with valve shows the biggest difference with the reusable mask are respiratory organics $(87.82 \%)$, nonrenewable energy $(85.32 \%)$, aquatic ecotoxicity $(72.45 \%)$, global warming $(69.37 \%)$, mineral extraction $(68.3 \%)$, aquatic acidification $(65.43 \%)$, terrestrial acidification/nutrification $(60.59 \%)$, non-carcinogens $(57.37 \%)$, respiratory inorganics $(57.17 \%)$, and ionizing radiation $(45.27 \%)$. It reflects 1.85 times and 3.91 times greater amount of Polypropylene material used to produce the FFP2 mask than cloth mask and surgical mask, respectively. However, of the fifteen impact categories listed in Table 9, cloth masks have three greater indicators than the FFP2 mask with valve: carcinogens with $62.06 \%$ difference, aquatic eutrophication $(54.43 \%)$, and ozone layer depletion $(27.43 \%)$. The higher impact is caused by the mask's filters requiring regular changing, while the other is produced once. In this result, there are two indicators in which surgical masks had values significantly higher than other masks: land occupation (93\% and $69.27 \%$ difference compared to FFP2 masks and cloth masks, respectively) and terrestrial ecotoxicity (45-50\% difference compared to others). A large quantity of disposable masks is required during its life cycle, and the overall amount of materials used to make the new masks is large as well. On the other hand, some of the raw materials to produce disposable masks make a big gap in some impact categories compared 
to the reusable mask, e.g., nose adapter (aluminum wire), nose protection (Polyurethane foam), valve (Polypropylene).

Table 9. Summary of the results of mid-point impact category for face mask based on the IMPACT 2002+ method.

\begin{tabular}{|c|c|c|c|c|c|}
\hline Impact Category & Unit & FFP2 with Valve & FFP2 without Valve & Surgical Mask & Cloth Mask \\
\hline Carcinogens & $\mathrm{kg} \mathrm{C}_{2} \mathrm{H}_{3} \mathrm{Cl}_{\mathrm{eq}}$ & $2.39 \times 10^{6}$ & $2.38 \times 10^{6}$ & $8.96 \times 10^{5}$ & $6.3 \times 10^{6}$ \\
\hline Non-carcinogens & $\mathrm{kg} \mathrm{C}_{2} \mathrm{H}_{3} \mathrm{Cl}_{\mathrm{eq}}$ & $2.51 \times 10^{6}$ & $1.11 \times 10^{6}$ & $1.61 \times 10^{6}$ & $1.07 \times 10^{6}$ \\
\hline Respiratory inorganics & $\mathrm{kg} \mathrm{PM}_{2.5 \mathrm{eq}}$ & $1.59 \times 10^{5}$ & $1.07 \times 10^{5}$ & $8.32 \times 10^{4}$ & $6.81 \times 10^{4}$ \\
\hline Ionizing radiation & $\mathrm{Bq} \mathrm{C}-14$ eq & $1.1 \times 10^{9}$ & $1.1 \times 10^{9}$ & $7.56 \times 10^{8}$ & $6.02 \times 10^{8}$ \\
\hline Ozone layer depletion & $\mathrm{kg} \stackrel{\mathrm{CFC}}{\mathrm{C}}-11_{\mathrm{eq}}$ & 16.4 & 16.1 & 21.4 & 22.6 \\
\hline Respiratory organics & $\mathrm{kg} \mathrm{C}_{2} \mathrm{H}_{4} \mathrm{eq}$ & $1.42 \times 10^{5}$ & $1.04 \times 10^{5}$ & $3.88 \times 10^{4}$ & $1.73 \times 10^{4}$ \\
\hline Aquatic ecotoxicity & $\mathrm{kg} \mathrm{TEG}$ water & $1.59 \times 10^{10}$ & $7.14 \times 10^{9}$ & $8.02 \times 10^{9}$ & $4.38 \times 10^{9}$ \\
\hline Terrestrial ecotoxicity & kg TEG soil & $1.04 \times 10^{9}$ & $1.03 \times 10^{9}$ & $2.06 \times 10^{9}$ & $1.14 \times 10^{9}$ \\
\hline Terrestrial acid/nutri & $\mathrm{kg} \mathrm{SO}_{2 \mathrm{eq}}$ & $2.69 \times 10^{6}$ & $1.94 \times 10^{6}$ & $1.7 \times 10^{6}$ & $1.06 \times 10^{6}$ \\
\hline Land occupation & $\mathrm{m}^{2}$ organic arable & $8.41 \times 10^{5}$ & $8.18 \times 10^{5}$ & $1.24 \times 10^{7}$ & $3.81 \times 10^{6}$ \\
\hline Aquatic acidification & $\mathrm{kg} \mathrm{SO}_{2 \mathrm{eq}}$ & $9.43 \times 10^{5}$ & $6.17 \times 10^{5}$ & $5.29 \times 10^{5}$ & $3.26 \times 10^{5}$ \\
\hline $\begin{array}{c}\text { Aquatic } \\
\text { eutrophication }\end{array}$ & $\mathrm{kg} \mathrm{PO}_{4}$ eq $\mathrm{P}-\mathrm{lim}$ & $1.49 \times 10^{4}$ & $1.45 \times 10^{4}$ & $1.3 \times 10^{4}$ & $3.27 \times 10^{4}$ \\
\hline Global warming & $\mathrm{kg} \mathrm{CO} 2 \mathrm{eq}$ & $1.75 \times 10^{8}$ & $1.26 \times 10^{8}$ & $8.43 \times 10^{7}$ & $5.36 \times 10^{7}$ \\
\hline Non-renewable energy & MJ primary & $6.64 \times 10^{9}$ & $4.35 \times 10^{9}$ & $2.5 \times 10^{9}$ & $9.75 \times 10^{8}$ \\
\hline Mineral extraction & MJ surplus & $1.06 \times 10^{7}$ & $1.06 \times 10^{7}$ & $8.84 \times 10^{6}$ & $3.36 \times 10^{6}$ \\
\hline
\end{tabular}

In the study period (306 days), as shown in Table 7, GHG emissions of producing and reusing (manual washing) of cotton cloth mask are $5.78 \times 10^{7} \mathrm{~kg} \mathrm{CO}_{2}$ eq, while FFP2 with valve is $1.96 \times 10^{8} \mathrm{~kg} \mathrm{CO}_{2}$ eq, FFP2 without valve is $1.37 \times 10^{8} \mathrm{~kg} \mathrm{CO}_{2}$ eq, and surgical mask is $9.20 \times 10^{7} \mathrm{~kg} \mathrm{CO}_{2}$ eq. Figure 6 shows the difference in $\mathrm{CO} 2$ eq emissions of different masks during mask production and usage phases. The amount of $\mathrm{CO}_{2 \text { eq }}$ emissions due to the FFP2 with valve is $100 \%$, the FFP2 without valve is reduced to only $69.9 \%$; this difference reduces to $46.9 \%$ and $29.5 \%$ for medical masks and cloth masks, respectively. Figure 7 compares the different face masks in value of $\mathrm{CO}_{2}$ eq emissions per Functional Unit during manufacturing and reusing phases. The one functional unit of cloth mask has the greatest value $\mathrm{CO}_{2}$ eq emissions to produce its and manual wash to reusing, but this impact will be offset by increasing the number of users and the duration of use. On a large scale, e.g., for the entire population of Italy, cloth masks still dominate in terms of $\mathrm{CO}_{2}$ eq emissions. However, the evaluation has not considered the transportation, packing, and waste treatment emission that is accounted as a significant source of GHGs emissions. If the average mass of each surgical mask is $2.54 \mathrm{~g}$ [42], the emission from the production phase was calculated from this study to be about 3 tonnes $\mathrm{CO}_{2}$ eq per tonne surgical mask. The transportation by air from China to Europe and waste incineration in Europe had estimated about 9.6 and 1.9 tonnes $\mathrm{CO}_{2}$ eq per tonne surgical masks, respectively [43]. It means that transporting contributes almost $66 \%$ of the total global warming potential of surgical masks.

Additionally, the washing activity may contribute to the degradation of the mask material and the reduction of protection. If changing from manual washing to machine washing, the amount of water, detergent, and electricity consumed will also increase, leading to increased social and environmental impacts. The adequate use and good cleaning of reusable masks can reduce $85 \%$ of waste and have a 3.39 times lower impact on climate change. 


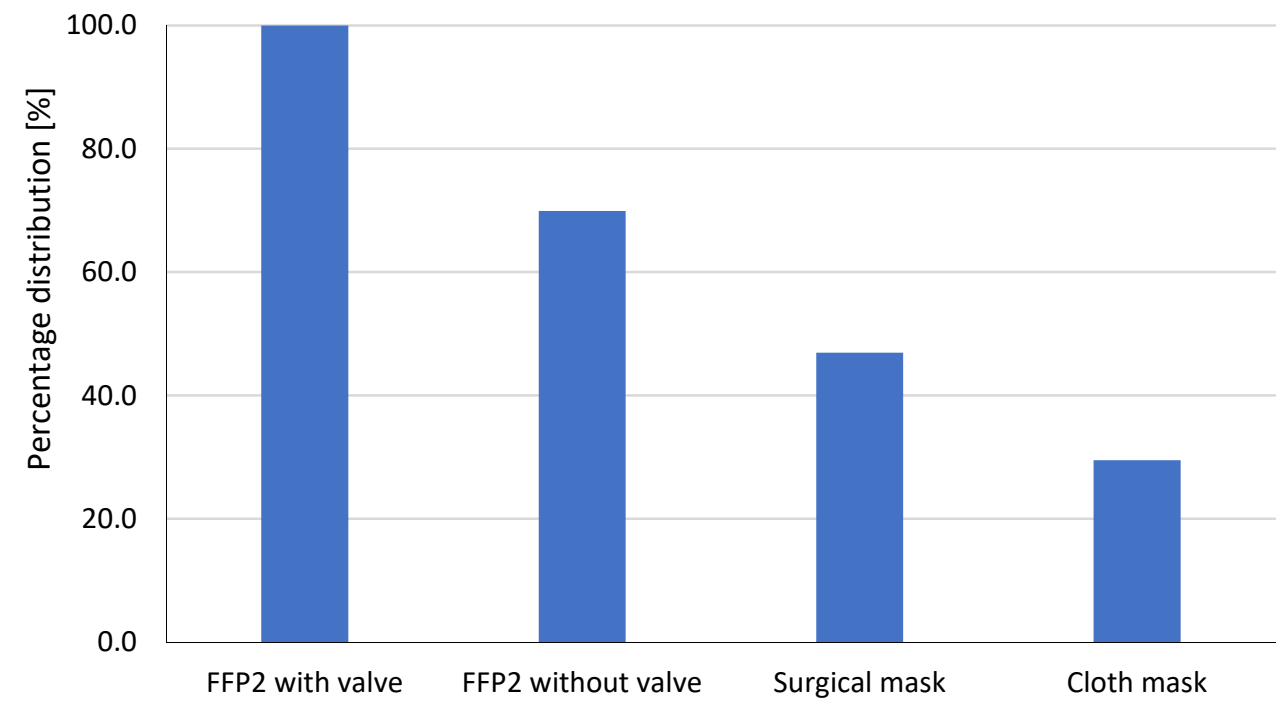

Figure 6. Percentage distribution of the Global Warming Potential (GWP) indicator.

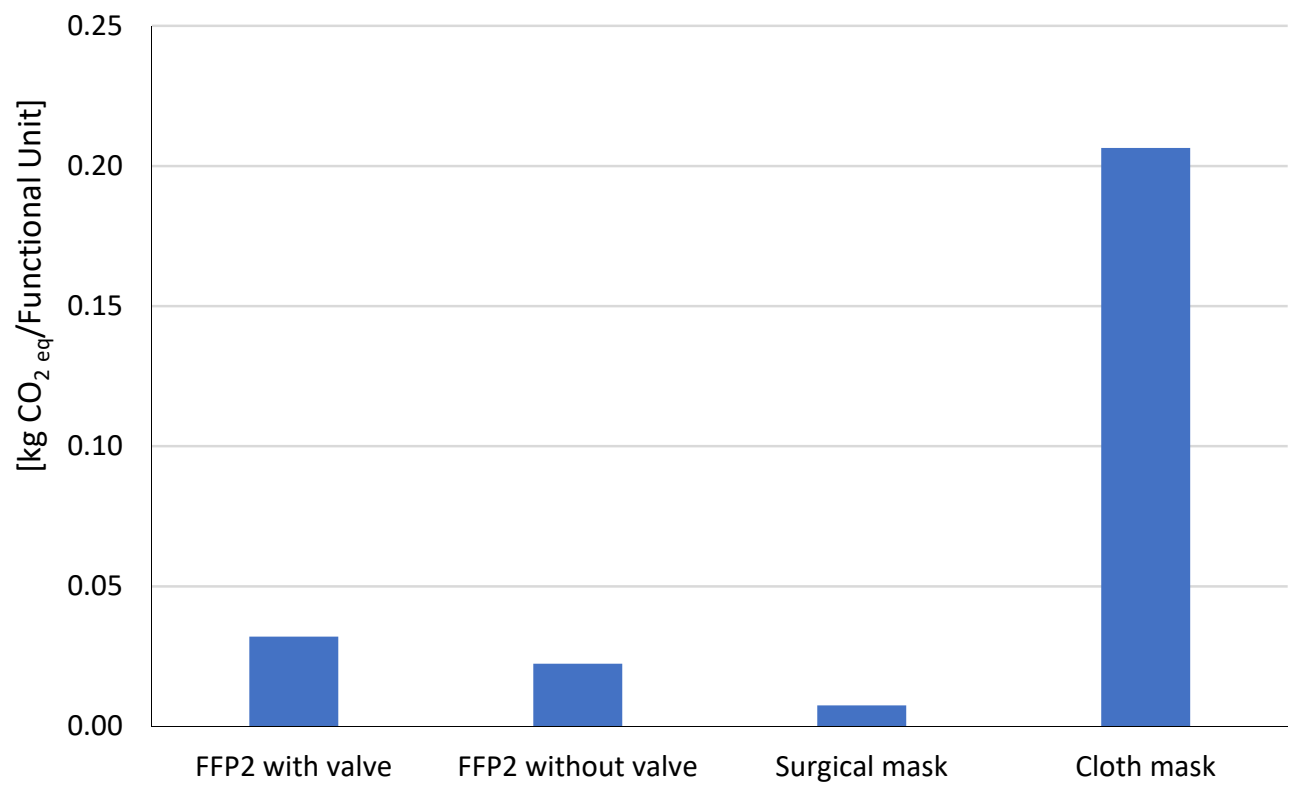

Figure 7. The Global Warming Potential (GWP) $\left[\mathrm{kg} \mathrm{CO}_{2}\right.$ eq $/$ Functional Unit] of the manufacturing and reusing phases.

\section{Future Perspective in Mask Development}

While the need for medical masks and respirators will continue to grow, the production and use of face masks pose environmental challenges, from greenhouse gas emissions to the amount of waste generated during production, and littering of public spaces. In the future, face masks should have intensive research as well as developmental efforts to improve their filtering performance and properties, and lead to greater convenience, comfort, user-friendliness, and lower cost. There are two areas for improvement in the designs of masks: the filterability of the mask material and additional technical functions and properties [2].

A thick layer of densely compacted fibers is required, and breathability is sacrificed to achieve the high removal properties of face masks. Various new membrane filters have been developed to clean particles with attractive properties such as higher specific surface area, smaller fiber diameters, transparency, low air resistance, electrostatic forces, or chemical bond interactions enhanced to improve performance. In the past five years, the 
most popular developed innovative air filtration materials are electret membranes [44-46], porous metal-organic framework- (MOF-) based filters [47-49], and polymer nanofiber membranes [50-52].

Wearing face masks has become the new measure during the COVID-19 pandemic. Using face masks has been strongly encouraged for the protection of the community and oneself against pathogenic. People may consider wearing reusable face masks, multifunctional versions, and those with smaller cost per wear. The face masks have been added with other functional properties, such as super-hydrophobicity [53], transparent quality, more comfort, convenience [54], self-cleaning or self-sterilizing [53], fashion, etc. In addition, intelligent mask designs also add opportunities for advanced features, like air quality sensors/monitors, biochemical or physical sensors, breath sensors [55], health trackers [56], microbe detectors [57], and even bone conduction headphones/earphones/microphones, etc.

On measures to limit the impact on the environment during the production and use of face masks, more sustainable practices are suggested, such as the use of plastics produced from renewable resources [58] or biodegradable materials [59], the use of renewable energy in production and transport, increased reusability, and proper disposal. The decontamination methods include physical methods (steam, heat (dry and humid), ultraviolet germicidal irradiation (UVGI)), and chemical methods (decontamination by ethylene oxide, bleach, vaporous hydrogen peroxide, and other chemical reagents was tested) $[60,61]$. However, labor-intensive, costly, and large-scale manufacturability may limit widespread application. The role of public awareness and education about using reusable masks is strongly understood, which may offer tools for proper usage, decontamination, and correct discarding of masks after use.

\section{Conclusions}

Nowadays, face masks have become an indispensable commodity, and even many products are manufactured to meet the needs of the world. Since the start of the COVID-19 pandemic, using face masks has become the norm for controlling the virus spreading and protecting personal and essential health care. Face masks are mostly made from petroleumbased non-renewable polymer materials that are non-degradable and dangerous for the environment and human health. This paper presented an overview of the membrane technology of face masks and the protection mechanism as well as their potential development. A comparative environmental analysis was performed on reusable and disposable masks used during the COVID-19 pandemic: cloth masks, surgical masks, and filtering facepiece respirators. It is shown that the respirators have the highest efficiency but are less sustainable and more environmentally impactful compared with other masks. Disposable masks present environmental challenges with significant environmental impacts of the manufacturing process, the tremendous amount of waste generated, and GHGs emissions. In the study period, the producing and using phase of FFP2 with valve mask emission was $1.96 \times 10^{8} \mathrm{~kg} \mathrm{CO}$ eq, 2.1 and 3.39 times higher than a surgical mask and cotton cloth mask (washed manually), respectively. The environmental mid-point impact category of the FFP2 mask also presents a big difference compared to the cloth mask, such as respiratory organics, non-renewable energy, aquatic ecotoxicity, global warming, mineral extraction, aquatic acidification, terrestrial acidification/nutrification, non-carcinogens, etc. On the other hand, the reusable mask seems to be more beneficial regarding prices. Cloth masks have low cost; they can be free if made from materials available at home like sweatshirts, towels, T-shirts, and scarves, while disposable masks can be on average 3.7 times more expensive.

In terms of functional units, cloth masks have a worse impact on the environment than FFP2 masks and medical masks. Still, it is the opposite in a wide range with a long time and a large population because a significantly large amount of material is used for disposable masks production. It provides an essential insight into the evolution of face mask production-oriented eco-design actions that require lower raw materials or can be recycled or reused. It has been promoting the development of mask materials and 
technology to be more environmentally friendly, convenient, comfortable, and fashionable. Developing washable face masks with high safety features is essential to reduce the massive pressure on disposable items in the COVID-19 pandemic.

Finally, there are some limitations which are worth being mentioned. This study considers the production and reuse phases of face masks, while packaging, transportation, disposal phases are dismissed due to lack of data. The ignored stages can contribute a considerable impact on the environment and affect the results quite a bit. As we all know, one of the harms of single-use masks to the environment is the large amount of waste, affecting the landscape. Quantifying the solid waste impacts is also not within the scope of this study. Therefore, future in-depth research on this issue needs to be investigated that can help track how the pandemic affected waste streams. The cloth mask results highly depend on the raw materials used, the number of wash times without losing filtering properties, and washing activity. The use of masks is determined by personal behavior, so the estimate of the number of masks needed, the number of hours to wear the masks, the amount of water and detergent used in washing, etc., is only approximate.

Furthermore, not all face masks used today are covered in this article. In this study, the primary data sources collected and published were used and analyzed using a numerical tool (SimaPro software), then the obtained results were used to make the evaluation. Since there were no available sensitivity and uncertainty analyses of the original data and no way to interfere with the original data source, it was omitted in this study.

The COVID-19 pandemic has forced the vast majority of our population to wear masks as a new norm. The COVID-19 pandemic is gradually being controlled worldwide, with a decreasing trend, but there is no certainty when it will end and predictions about a similar pandemic in the future. The preventive role of masks is indisputable, but their impact on the environment also needs to be considered. This study's results can be considered a recommendation for policy makers from the environmental and ecosystem impact of masks and to guide public opinion in mask selection and its usage.

Author Contributions: Supervision, A.J.T.; writing—original draft preparation, H.T.D.T.; funding acquisition, P.M. All authors have read and agreed to the published version of the manuscript.

Funding: This research was funded by OTKA, grant number 128543.

Institutional Review Board Statement: Not applicable.

Informed Consent Statement: Not applicable.

Data Availability Statement: Not applicable.

Acknowledgments: This publication was supported by OTKA 131586. The research was supported by the EU LIFE program, LIFE-CLIMCOOP project (LIFE19 CCA/HU/001320). The research reported in this paper and carried out at the Budapest University of Technology and Economics has been supported by the National Research Development and Innovation Fund (TKP2020 National Challenges Subprogram, Grant No. BME-NC) based on the charter of bolster issued by the National Research Development and Innovation Office under the auspices of the Ministry for Innovation and Technology.

Conflicts of Interest: The authors declare no conflict of interest.

\section{References}

1. WHO. WHO Coronavirus (COVID-19) Dashboard. Available online: https:/ / covid19. who.int (accessed on 10 October 2021).

2. Chua, M.H.; Cheng, W.; Goh, S.S.; Kong, J.; Li, B.; Lim, J.Y.C.; Mao, L.; Wang, S.; Xue, K.; Yang, L.; et al. Face Masks in the New COVID-19 Normal: Materials, Testing, and Perspectives. Research 2020, 2020, 7286735. [CrossRef]

3. Chowdhury, H.; Chowdhury, T.; Sait, S.M. Estimating marine plastic pollution from COVID-19 face masks in coastal regions. Mar. Pollut. Bull. 2021, 168, 112419. [CrossRef]

4. Tcharkhtchi, A.; Abbasnezhad, N.; Zarbini Seydani, M.; Zirak, N.; Farzaneh, S.; Shirinbayan, M. An overview of filtration efficiency through the masks: Mechanisms of the aerosols penetration. Bioact. Mater. 2021, 6, 106-122. [CrossRef] [PubMed]

5. Bar-On, Y.M.; Flamholz, A.; Phillips, R.; Milo, R. SARS-CoV-2 (COVID-19) by the numbers. Elife 2020, 9, e57309. [CrossRef] 
6. Hinds, W.C. Filtration. In Aerosol Technology: Properties, Behavior, and Measurement of Airborne Particles, 2nd ed.; John Wiley \& Sons: New York, NY, USA, 1999; pp. 182-205.

7. Dunnett, S. Filtration Mechanisms. Aerosol Sci. 2013, 89-117. [CrossRef]

8. Bayersdorfer, J.; Giboney, S.; Martin, R.; Moore, A.; Bartles, R. Novel Manufacturing of Simple Masks in Response to International Shortages: Bacterial and Particulate Filtration Efficiency Testing. Am. J. Infect. Control. 2020, 48, 1543-1545. [CrossRef] [PubMed]

9. Konda, A.; Prakash, A.; Moss, G.; Schmoldt, M.; Grant, G.; Guha, S. Aerosol Filtration Efficiency of Common Fabrics Used in Respiratory Cloth Masks. ACS Nano 2020, 14, 6339-6347. [CrossRef] [PubMed]

10. Prata, J.; Patricio Silva, A.L.; Duarte, A.; Rocha-Santos, T. Disposable over Reusable Face Masks: Public Safety or Environmental Disaster? Environments 2021, 8, 31. [CrossRef]

11. Adyel, T.M. Accumulation of plastic waste during COVID-19. Science 2020, 369, 1314.

12. Fadare, O.O.; Okoffo, E.D. Covid-19 face masks: A potential source of microplastic fibers in the environment. Sci. Total Environ. 2020, 737, 140279. [CrossRef]

13. Selvaranjan, K.; Navaratnam, S.; Rajeev, P.; Ravintherakumaran, N. Environmental challenges induced by extensive use of face masks during COVID-19: A review and potential solutions. Environ. Chall. 2021, 3, 100039. [CrossRef]

14. Klemeš, J.J.; Fan, Y.V.; Jiang, P. The energy and environmental footprints of COVID-19 fighting measures-PPE, disinfection, supply chains. Energy 2020, 211, 118701. [CrossRef]

15. Wang, Z.; Guy, C.; Ng, K.T.; An, C. A New Challenge for the Management and Disposal of Personal Protective Equipment Waste during the COVID-19 Pandemic. Sustainability 2021, 13, 7034. [CrossRef]

16. Oginni, O. COVID-19 disposable face masks: A precursor for synthesis of valuable bioproducts. Environ. Sci. Pollut. Res. Int. 2021, 28, 1-3. [CrossRef]

17. Silva, A.L.P.; Prata, J.C.; Duarte, A.C.; Soares, A.M.V.M.; Barceló, D.; Rocha-Santos, T. Microplastics in landfill leachates: The need for reconnaissance studies and remediation technologies. Case Stud. Chem. Environ. Eng. 2021, 3, 100072. [CrossRef]

18. Jeong, J.; Choi, J. Adverse outcome pathways potentially related to hazard identification of microplastics based on toxicity mechanisms. Chemosphere 2019, 231, 249-255. [CrossRef]

19. Jambeck, J.; Geyer, R.; Wilcox, C.; Siegler, T.; Perryman, M.; Andrady, A.; Narayan, R.; Law, K. Marine pollution. Plastic waste inputs from land into the ocean. Science 2015, 347, 768-771. [CrossRef]

20. Ayse, L.A.; Ambrose-Dempster, E.; Aparsi, T.D.; Bawn, M.; Arredondo, M.C.; Chau, C.; Chandler, K.; Dobrijevic, D.; Hailes, H.; Lettieri, P.; et al. The environmental dangers of employing single-use face masks as part of a COVID-19 exit strategy. UCL Open Environ. Prepr. 2020. Available online: https:/ / ucl.scienceopen.com (accessed on 10 August 2021).

21. Rizan, C.; Reed, M.; Bhutta, M. Environmental impact of Personal Protective Equipment supplied to health and social care services in England in the first six months of the COVID-19 pandemic. J. R. Soc. Med. 2020, 9, 20198911.

22. Rengasamy, S.; Eimer, B.; Shaffer, R.E. Simple Respiratory Protection-Evaluation of the Filtration Performance of Cloth Masks and Common Fabric Materials Against 20-1000 nm Size Particles. Ann. Occup. Hyg. 2010, 54, 789-798.

23. Shutler, T.M.A.N. How to Sew a Fabric Face Mask. The New York Times, 31 March 2020.

24. Lepelletier, D.; Grandbastien, B.; Romano-Bertrand, S.; Aho, S.; Chidiac, C.; Géhanno, J.F.; Chauvin, F. What face mask for what use in the context of the COVID-19 pandemic? The French guidelines. J. Hosp. Infect. 2020, 105, 414-418. [CrossRef]

25. Yao, B.-G.; Wang, Y.-X.; Ye, X.-Y.; Zhang, F.; Peng, Y.-L. Impact of structural features on dynamic breathing resistance of healthcare face mask. Sci. Total Environ. 2019, 689, 743-753. [CrossRef] [PubMed]

26. Lee, S.-A.; Hwang, D.-C.; Li, H.-Y.; Tsai, C.-F.; Chen, C.-W.; Chen, J.-K. Particle Size-Selective Assessment of Protection of European Standard FFP Respirators and Surgical Masks against Particles-Tested with Human Subjects. J. Healthc. Eng. 2016, 2016, 8572493. [CrossRef] [PubMed]

27. Lepelletier, D.; Keita-Perse, O.; Parneix, P.; Baron, R.; Glélé, L.S.A.; Grandbastien, B. Respiratory protective equipment at work: Good practices for filtering facepiece (FFP) mask. Eur. J. Clin. Microbiol. Infect. Dis. 2019, 38, 2193-2195. [CrossRef]

28. Das, S.; Sarkar, S.; Das, A.; Das, S.; Chakraborty, P.; Sarkar, J. A comprehensive review of various categories of face masks resistant to Covid-19. Clin. Epidemiol. Glob. Health 2021, 12, 100835. [CrossRef]

29. Liao, M.; Liu, H.; Wang, X.; Hu, X.; Huang, Y.; Liu, X.; Brenan, K.; Mecha, J.; Nirmalan, M.; Lu, J. A Technical Review of Face Mask Wearing in Preventing Respiratory COVID-19 Transmission. Curr. Opin. Colloid Interface Sci. 2021, 52, 101417. [CrossRef]

30. Dharmaraj, S.; Ashokkumar, V.; Hariharan, S.; Manibharathi, A.; Show, P.L.; Chong, C.T.; Ngamcharussrivichai, C. The COVID-19 pandemic face mask waste: A blooming threat to the marine environment. Chemosphere 2021, 272, 129601. [CrossRef]

31. Hasan, N.A.; Heal, R.D.; Bashar, A.; Haque, M.M. Face masks: Protecting the wearer but neglecting the aquatic environment?-A perspective from Bangladesh. Environ. Chall. 2021, 4, 100126. [CrossRef]

32. Wrisberg, N.; Haes, H.; Triebswetter, U.; Eder, P.; Clift, R. Analytical Tools for Environmental Design and Management in a Systems Perspective: The Combined Use of Analytical Tools; Springer: Berlin/Heidelberg, Germany, 2002.

33. Aziz, N.I.H.A.; Hanafiah, M.M. Application of life cycle assessment for desalination: Progress, challenges and future directions. Environ. Pollut. 2021, 268, 115948. [CrossRef]

34. Bare, J.C.; Hofstetter, P.; Pennington, D.W.; de Haes, H.A.U. Midpoints versus endpoints: The sacrifices and benefits. Int. J. Life Cycle Assess. 2000, 5, 319. [CrossRef]

35. Hauschild, M.Z.; Huijbregts, M.A.J. Introducing Life Cycle Impact Assessment. In Life Cycle Impact Assessment; Hauschild, M.Z., Huijbregts, M.A.J., Eds.; Springer: Dordrecht, Netherlands, 2015; pp. 1-16. 
36. Simapro. Available online: https://simapro.com/ (accessed on 10 August 2021).

37. Rodríguez, N.B.; Formentini, G.; Favi, C.; Marconi, M. Environmental implication of personal protection equipment in the pandemic era: LCA comparison of face masks typologies. Procedia CIRP 2021, 98, 306-311. [CrossRef] [PubMed]

38. Statista Inc. Energy Consumption in Italy in 2020, by Source. Available online: https://www.statista.com/ (accessed on 1 November 2021).

39. Jolliet, O.; Margni, M.; Charles, R.; Humbert, S.; Payet, J.; Rebitzer, G.; Rosenbaum, R. IMPACT 2002+: A new life cycle assessment methodology. Int. J. Life Cycle Assess. 2003, 8, 324-330. [CrossRef]

40. Huijbregts, M.; Steinmann, Z.; Elshout, P.; Stam, G.; Verones, F.; Vieira, M.; Zijp, M.; Hollander, A.; Zelm, R. ReCiPe2016: A harmonised life cycle impact assessment method at midpoint and endpoint level. Int. J. Life Cycle Assess. 2016, $22,138-147$. [CrossRef]

41. Hischier, R.; Weidema, B.; Althaus, H.-J.; Bauer, C.; Doka, G.; Dones, R.; Frischknecht, R.; Hellweg, S.; Humbert, S.; Jungbluth, N.; et al. Implementation of Life Cycle Impact Assessment Methods. Final. Rep. Ecoinvent 2010, 2, v2.

42. Fernández-Arribas, J.; Moreno, T.; Bartrolí, R.; Eljarrat, E. COVID-19 face masks: A new source of human and environmental exposure to organophosphate esters. Environ. Int. 2021, 154, 106654. [CrossRef] [PubMed]

43. Graulich, K.; Köhler, A.; Löw, C.; Sutter, J.; Watson, D.; Mehlhart, G.; Egebæk, K.R.; Bilsen, V.; Bley, F.; Manshoven, S.; et al. Impact of COVID-19 on Single-Use Plastics and the Environment in Europe; European Environment Agency: Boeretang, Belgium, 22 June 2021.

44. Liu, F.; Li, M.; Shao, W.; Yue, W.; Hu, B.; Weng, K.; Chen, Y.; Liao, X.; He, J. Preparation of a polyurethane electret nanofiber membrane and its air-filtration performance. J. Colloid Interface Sci. 2019, 557, 318-327. [CrossRef]

45. Bai, Y.; Han, C.B.; He, C.; Gu, G.Q.; Nie, J.H.; Shao, J.J.; Xiao, T.X.; Deng, C.R.; Wang, Z.L. Washable Multilayer Triboelectric Air Filter for Efficient Particulate Matter PM2.5 Removal. Adv. Funct. Mater. 2018, 28, 1706680. [CrossRef]

46. Lai, Y.-C.; Deng, J.; Zhang, S.L.; Niu, S.; Guo, H.; Wang, Z.L. Single-Thread-Based Wearable and Highly Stretchable Triboelectric Nanogenerators and Their Applications in Cloth-Based Self-Powered Human-Interactive and Biomedical Sensing. Adv. Funct. Mater. 2017, 27, 1604462. [CrossRef]

47. Hao, Z.; Wu, J.; Wang, C.; Liu, J. Electrospun Polyimide/Metal-Organic Framework Nanofibrous Membrane with Superior Thermal Stability for Efficient PM2.5 Capture. ACS Appl. Mater. Interfaces 2019, 11, 11904-11909. [CrossRef] [PubMed]

48. Koo, W.-T.; Jang, J.-S.; Qiao, S.; Hwang, W.; Jha, G.; Penner, R.M.; Kim, I.-D. Hierarchical Metal-Organic Framework-Assembled Membrane Filter for Efficient Removal of Particulate Matter. ACS Appl. Mater. Interfaces 2018, 10, 19957-19963. [CrossRef]

49. Chen, Y.; Zhang, S.; Cao, S.; Li, S.; Chen, F.; Yuan, S.; Xu, C.; Zhou, J.; Feng, X.; Ma, X.; et al. Roll-to-Roll Production of Metal-Organic Framework Coatings for Particulate Matter Removal. Adv. Mater. 2017, 29, 1606221. [CrossRef]

50. Li, Q.; Xu, Y.; Wei, H.; Wang, X. An electrospun polycarbonate nanofibrous membrane for high efficiency particulate matter filtration. RSC Adv. 2016, 6, 65275-65281.

51. Yang, X.; Pu, Y.; Zhang, Y.; Liu, X.; Li, J.; Yuan, D.; Ning, X. Multifunctional composite membrane based on BaTiO3@PU/PSA nanofibers for high-efficiency PM2.5 removal. J. Hazard. Mater. 2020, 391, 122254. [CrossRef] [PubMed]

52. Gao, X.; Li, Z.-K.; Xue, J.; Qian, Y.; Zhang, L.-Z.; Caro, J.; Wang, H. Titanium carbide Ti3C2Tx (MXene) enhanced PAN nanofiber membrane for air purification. J. Membr. Sci. 2019, 586, 162-169. [CrossRef]

53. Zhong, H.; Zhu, Z.; Lin, J.; Cheung, C.F.; Lu, V.L.; Yan, F.; Chan, C.-Y.; Li, G. Reusable and Recyclable Graphene Masks with Outstanding Superhydrophobic and Photothermal Performances. ACS Nano 2020, 14, 6213-6221. [CrossRef]

54. Lin, Y.-C.; Chen, C.-P. Thermoregulation and thermal sensation in response to wearing tight-fitting respirators and exercising in hot-and-humid indoor environment. Build. Environ. 2019, 160, 106158. [CrossRef]

55. Güder, F.; Ainla, A.; Redston, J.; Mosadegh, B.; Glavan, A.; Martin, T.J.; Whitesides, G.M. Paper-Based Electrical Respiration Sensor. Angew. Chem. Int. Ed. 2016, 55, 5727-5732. [CrossRef] [PubMed]

56. Cherrie, J.W.; Wang, S.; Mueller, W.; Wendelboe-Nelson, C.; Loh, M. In-mask temperature and humidity can validate respirator wear-time and indicate lung health status. J. Expo. Sci. Environ. Epidemiol. 2019, 29, 578-583. [CrossRef]

57. Williams, C.M.; Abdulwhhab, M.; Birring, S.S.; De Kock, E.; Garton, N.J.; Townsend, E.; Pareek, M.; Al-Taie, A.; Pan, J.; Ganatra, R.; et al. Exhaled Mycobacterium tuberculosis output and detection of subclinical disease by face-mask sampling: Prospective observational studies. Lancet Infect. Dis. 2020, 20, 607-617. [CrossRef]

58. Gorrasi, G.; Sorrentino, A.; Lichtfouse, E. Back to plastic pollution in COVID times. Environ. Chem. Lett. 2021, 19, 1-4. [CrossRef]

59. Babaahmadi, V.; Amid, H.; Naeimirad, M.; Ramakrishna, S. Biodegradable and multifunctional surgical face masks: A brief review on demands during COVID-19 pandemic, recent developments, and future perspectives. Sci. Total Environ. 2021, 798, 149233. [CrossRef]

60. Oyu Tsogtbayar, C.Y. The Decontamination of Mask and Reuse: Evidence Review. Korean J. Public Health 2020, 57, 17-24. [CrossRef]

61. Ma, Q.X.; Shan, H.; Zhang, C.M.; Zhang, H.L.; Li, G.M.; Yang, R.M.; Chen, J.M. Decontamination of face masks with steam for mask reuse in fighting the pandemic COVID-19: Experimental supports. J. Med. Virol. 2020, 92, 1971-1974. [CrossRef] [PubMed] 